Review

\title{
Carbonated Dairy Beverages: Challenges and Opportunities
}

\author{
Daniel Newbold and Kadri Koppel * \\ Center for Sensory Analysis and Consumer Behavior, Kansas State University, 1310 Research Park Dr, \\ Manhattan, KS 66502, USA; dan29@k-state.edu \\ * Correspondence: kadri@ksu.edu; Tel.: +1-785-532-0163
}

Received: 25 July 2018; Accepted: 28 August 2018; Published: 2 September 2018

\begin{abstract}
Yogurt drinks have seen a $66 \%$ increase in consumption in the United States over the last five years. Even though there has been an increase in yogurt drink consumption, the market share of drinkable dairy beverages remains small. Carbonated dairy beverages have become increasingly popular in recent years, and innovations in this area could help drive increased consumption of these beverages. Currently traditionally carbonated dairy beverages, like kefir, are the most popular carbonated dairy beverages on the market. Carbonation at appropriate levels in dairy products, especially dairy beverages, has been shown to improve the sensory attributes, quality, and shelf life of these products. Probiotics, which are added to yogurt drinks for their health benefits, are not harmed or negatively affected by carbonation. Several methods have been developed to carbonate dairy beverages in a manufacturing setting, although these methods have not been widely applied to commercially available products. The increased consumption of dairy beverages and the benefits of carbonation upon these beverages means that there are opportunities to develop widely accepted and popular carbonated dairy beverages. The objective of this article was to review available literature on carbonated dairy beverages and to discuss the challenges and opportunities in this area.
\end{abstract}

Keywords: Carbonation; dairy; drinkable yogurt; carbonated yogurt; carbonated beverage

\section{Introduction}

The largest segment of dairy beverages currently consumed in the United States is milk. Milk has been declining in sales in recent years in part because of its public perception as being less healthy than other alternatives. Even though milk sales have been declining, drinkable yogurt is poised for significant growth, as indicated by current consumer trends. Spoonable and Greek-style yogurts make up a majority of the market share of yogurt. Despite spoonable yogurts' popularity, both the novelty and the interest in spoonable yogurt products has begun to wane [1]. Meanwhile, drinkable yogurts have begun to become increasingly popular. According to Mintel Reports [1], drinkable yogurts have seen a powerful growth of $66 \%$ from 2012 to 2017. Yogurt consumption has typically been the highest among children, with $38 \%$ of yogurt drinks being consumed by children [2]. Growth in the drinkable yogurt segment would require increased consumption by various age groups, not just children. There is a possibility to increase the consumption of yogurt drinks, with $41 \%$ of non-yogurt drinkers reporting that they would be willing to try yogurt drinks [2]. Increased yogurt drink consumption by adults would require the development of yogurt beverages that appeal to adults, such as a wider variety of adult flavor offerings, decreased sugar content, and higher protein levels.

A recent study showed how yogurt is perceived to be healthy, which may explain why yogurt and yogurt drinks are growing in popularity [3]. In that study, the consumers had yogurt samples presented to them, and were also asked questions about their yogurt consumption, which resulted in the findings that consumer panelists enjoyed yogurt drinks that had a medium sweetness and 
high viscosity. It was generally understood by consumers that yogurt is a healthy food because it contains probiotics and sometimes prebiotics. However, most consumers did not understand what probiotics/prebiotics are and what their benefits are [3].

Carbonated dairy beverages are beverages that are dairy based such as yogurt, milk, buttermilk, etc. and that have been carbonated through either microbiological or physical methods. The addition of carbonation in these beverages results in a tingling effect upon consumption, which alters the consumers' sensory experience. There has been an increase in the interest, consumption, and availability of carbonated dairy beverages in recent years. For example, many grocery stores in the United States now sell kefirs, which were not as widely available even a decade ago. According to Tamime and Robinson [4], "Soft drinks are extremely popular worldwide, and a yoghurt beverage (flavored with natural orange, lemon, cherry, or apple) has the effect of improving the thirst-quenching quality and refreshing taste of ordinary yoghurt, and causing a pleasant tingling sensation on the tongue." Carbonated drinkable yogurts may be a good option that would be available on the market for those seeking carbonated beverages.

This article will review and discuss several different aspects of carbonation as they relate to dairy beverages. Carbonation has been found to have a definite effect on the sensory attributes, quality attributes, and probiotic content of dairy and yogurt beverages. There are various types of carbonated yogurt beverages that are currently on the market. The carbonated dairy beverages that will be discussed, include kefir, koumiss, and some lesser known beverages. Trends and research will also be discussed, as well as the challenges and opportunities related to this unique beverage category.

\section{Carbonated Dairy Beverages}

It is important to understand what carbonated dairy beverages are currently being sold on the market, and what carbonated dairy beverages are traditionally consumed, in order to understand what opportunities may exist for further developments of carbonated dairy beverages. For this review, types of carbonated dairy beverages may be split up into two separate categories (Table 1). The first category includes dairy beverages that are carbonated by the addition of yeast to the fermentable substrate, which produces carbon dioxide during the fermentation process. The second category includes dairy beverages that are carbonated by mechanical or physical means during regular food plant processing.

Table 1. Carbonated dairy beverages.

\begin{tabular}{llll}
\hline \multicolumn{1}{c}{ Beverage } & \multicolumn{1}{c}{ Type } & \multicolumn{1}{c}{ Ingredients } & \multicolumn{1}{c}{ Notes } \\
\hline Kefir & $\begin{array}{l}\text { Carbonated by yeast } \\
\text { addition prior to } \\
\text { fermentation }\end{array}$ & $\begin{array}{l}\text { Bovine milk, kefir grains (wildly } \\
\text { cultivated yeasts, lactic acid } \\
\text { bacteria, acetic acid bacteria, and } \\
\text { molds) [5] }\end{array}$ & $\begin{array}{l}\text { Originated in Russia, popular in the } \\
\text { United States [6] }\end{array}$ \\
\hline \multirow{3}{*}{ Koumiss } & $\begin{array}{l}\text { Carbonated by yeast } \\
\text { addition prior to } \\
\text { fermentation }\end{array}$ & $\begin{array}{l}\text { Mares milk, thermophilic lactic } \\
\text { acid bacteria (Leuconostoc, } \\
\text { Lactobacilli), yeast [5] }\end{array}$ & $\begin{array}{l}\text { Traditionally consumed in the Middle } \\
\text { East [5] }\end{array}$ \\
\hline \multirow{5}{*}{$\begin{array}{l}\text { Sparkling } \\
\text { Milk }\end{array}$} & $\begin{array}{l}\text { Carbonated milk } \\
\text { (carbonated through } \\
\text { processing) }\end{array}$ & $\begin{array}{l}\text { E-moo: Non-fat milk, calcium, } \\
\text { flavorings, fructose [7] } \\
\text { Raging Cow: Milk, flavorings, } \\
\text { sweeteners, etc. } \\
\text { Swerve: Milk, flavorings, sugar, } \\
\text { sucralose, vitamins }\end{array}$ & $\begin{array}{l}\text { E-moo: Launched in 2001 with the } \\
\text { collaboration of Cornell University [7] } \\
\text { Raging Cow: Created by Dr. } \\
\text { Pepper/Snapple in 2003 } \\
\text { Swerve: Introduced by Coca-Cola in } \\
\text { 2003, it was discontinued in 2005 }\end{array}$ \\
\hline
\end{tabular}

\subsection{Yeast Addition}

Some of the most commonly studied carbonated dairy beverages are kefir and koumiss. Traditional kefir has been cultured for centuries, originating from the Caucasus mountain region in Russia [8]. The traditional fermentation of these types of beverages leads to the release and development of lactic acid, alcohol, carbon dioxide, and aromatic flavoring compounds [4]. 


\subsubsection{Kefir}

Drinkable dairy beverages have seen a rise in overall sales over the course of the last five years [1]. This increase has, in part, been due to the increasing popularity of kefir, which has become increasingly available, even in the United States where kefir is a novel product. While there is no FDA-regulated standard definition for kefir, it is generally made by adding kefir grains to milk, and allowing the milk to ferment until a liquid, slightly carbonated, ethanol-containing yogurt beverage is created [5]. Kefir grains are small grain-like matrices of lactic acid bacteria, acetic acid bacteria, yeast, casein, polysaccharide, and sugars, which are used during fermentation, and generally contain cultures that have been cultivated wildly over time [5]. These grains contain different species of yeast, lactic acid bacteria, acetic acid bacteria, molds, and sometimes other organisms that are typically seen as being contaminants in other dairy products [5]. Kefir has been traditionally consumed in Russia and some central Asian countries [6]. According to Arslan [6], kefir has been increasing in popularity recently in Europe, Japan, and the United States, which may be due to some nutritional and therapeutic effects that kefir may have. From a nutritional standpoint, kefir contains vitamins such as B1, B2, B5, and C; kefirs also contain amino acids and minerals such as calcium, magnesium, and phosphorus. Kefir has been noted to be especially good for those who are lactose intolerant and want to consume dairy, because kefir has an especially high B-galactosidase activity, an enzyme which breaks down lactose over the long 12-24 $\mathrm{h}$ fermentation time for the production of kefir.

As stated, part of the reason for increasing kefir consumption is related to its potential health benefits [9]. Much of the recent research done on kefir is related to kefir health benefits and the validity of the perceived health benefits. When discussing the health benefits of kefir, the scientific research has been centered on therapeutic health benefits rather than the well-known benefits of vitamins/nutrients that are naturally present in kefir. Gastrointestinal proliferation, antibacterial spectrum, anticarcinogenic effects, hypocholesteremic effects, antidiabetic properties, antimutagenic activity, B-galactosidase activity, lactic acid content, effects on lipid and blood pressure level, protection against apoptosis, antiallergenic properties, anti-inflammatory action, bacterial colonization, and immune system booster are some of the reported benefits of kefir that have not been well researched through peer-reviewed studies. While all of these therapeutic health benefits of kefir have been studied, it is critical to note that the amount and quality of the research varies in these areas. Other areas of research, especially antidiabetic properties, antiallergenic properties, antioxidative effects, blood pressure effects, and apoptosis, need much more scientific research before they can be considered to have valid therapeutic health benefits. Guzel-Seydim et al. [10] confirmed these findings in a review of the functional health benefits research of kefir. Antimutagenic/anticarcinogenic properties, cholesterol effects, antimicrobial effects, immune system, and lactose intolerance have all been shown to have extensive and well documented studies [10].

While health benefits have their place in driving kefir sales and research, there has also been research in the application of kefir cultures to other new and innovative products. Much research has been carried out in recent years on products that can be made using whey, which is a byproduct of dairy product production, especially in cheese making. Abdolmaleki et al. [11] used kefir cultures to create kefir beverages out of three different substrates, milk, whey, and soy. Whey was used to see if this byproduct could be used for a unique dairy beverage, and soy was used for a non-dairy option. The three beverages, when compared based on physical attributes and bacterial enumerations, showed very little difference on important sensory and physical attributes over the course of four weeks of analysis. This proved, along with other research on this subject, that kefir grains may be used to ferment and culture new and novel products.

\subsubsection{Koumiss}

While koumiss is currently not popular in the United States, it is a unique and popular drink in the Middle East that is carbonated by natural yeasts. Koumiss differs from kefir in that it is traditionally made with mare's milk, and that the cultures do not come in the form of grains. The cultures and 
identity for koumiss are not defined by regulation, but all koumiss products will typically contain thermophilic bacteria and yeast [5]. Collection and speciation of random koumiss samples revealed that the microbiological population of koumiss varies widely, since the strains are wildly harvested. At least 55 different stains of various Lactobacillus and Leuconostoc species have been identified in wild koumiss [12]. At least 12 different yeast species belonging to nine different genera were identified as being the main yeast species in koumiss [13]. Health trends seem to be a continuing topic of discussion for carbonated dairy beverages like kefir and koumiss. There is substantially less peer-reviewed research that has been conducted on the health benefits of koumiss. It is interesting to note that as early as in the 19th century, koumiss health centers were set up in the steppes of Russia where travelers would come to receive treatment by consuming koumiss, and efforts have been made to bring back similar centers today to promote tourism in the region [14].

\subsection{Other Carbonation Methods}

While kefir and koumiss are dairy beverages that have been carbonated by yeast that is incorporated with the inoculum, dairy beverages may also be carbonated through other methods. Carbonated dairy beverages can be manufactured by either a liquid or a dry process. The dry process involves the addition of a powder to the liquid base that releases carbon dioxide upon mixing [4]. Several different patents have been filed, and these methods exist for the carbonation of yogurt or yogurt beverages, as well as other dairy products. One unique method is using a protein whipping agent, which is added to yogurt and shaken to aerate and carbonate the yogurt [15]. This method is uncommon, and it is not clear whether this has ever been applied to a commercially available beverage. The milk may be carbonated prior to culturing if the carbonated yogurt is to be made [16]. This method is well defined by Gueimonde and Clara [17]; however it remains to be seen how widely this method is applied in the industry. The last method, and probably the most common method in the industry, is the carbonation of homogenized finished products, as illustrated in the trials done by Choi and Kosikowski [18].

Carbonated milks and dairy beverages carbonated by physical means have been introduced into the market for sale in the past. In the early 2000s, various carbonated milks were introduced into the marketplace, including E-moo, which was a carbonated milk that was being tested in some schools in the eastern United States [7]. Coca-Cola and Dr. Pepper/Snapple also launched or tested their own carbonated milk products in the early 2000s, these products being on the market for one to two years before being discontinued. These products may have discontinued for a variety of reasons, one being that there is much unfamiliarity in the United States with carbonated dairy drinks, which may lead to hesitation in buying them. Although some carbonated dairy beverages are available in the United State through e-commerce, there are many carbonated dairy beverages that are consumed outside of the United States, such as Doogh from India, and Calpis from Japan. Overall, most of the carbonated dairy drinks consumed in the United States are yogurts or kefirs that contain yeast.

\section{Carbonation}

The sensory attributes of carbonated beverages and how the carbonation effects consumer likability has been well-studied. There are many carbonated beverages, mostly in markets that rely on carbonation to deliver an expected sensory experience that will drive consumption. There is ample research on carbonation and its effects on the sensory attributes of dairy beverages. In addition, there is also research that focuses on carbonation's effect on shelf-life/quality, and in the case of yogurt beverages, probiotic levels.

\subsection{Sensory Aspects}

While carbonated soft drinks are popular and well known throughout the world, carbonation is somewhat of a unique attribute to mix with dairy beverages for many Americans. Relevant literature on carbonated dairy drinks has been summarized in Table 2 . 
Table 2. Literature on carbonated dairy beverages.

\begin{tabular}{|c|c|c|c|c|}
\hline Author(s) & Base/Substrate & Ingredients & $\begin{array}{l}\text { Carbonation Levels } \\
\text { (given as a pressure) }\end{array}$ & Key Findings \\
\hline \multicolumn{5}{|c|}{ Carbonated Milk } \\
\hline Chang et al. [19] & Carbonated milk & $\begin{array}{l}\text { Milk, NFDM (Non-Fat } \\
\text { Dried Milk) }\end{array}$ & $\begin{array}{l}0.35,0.7 \text {, and } \\
1.05 \mathrm{~kg} / \mathrm{cm}^{2}\end{array}$ & $\begin{array}{l}\text { Carbonation increased } \\
\text { milk viscosity and } \\
\text { shelf-life }\end{array}$ \\
\hline Lederer et al. [20] & $\begin{array}{l}\text { Flavored } \\
\text { carbonated milks }\end{array}$ & $\begin{array}{l}\text { Milk, sugar, flavoring, } \\
\text { colorant }\end{array}$ & $\begin{array}{l}0.07 \mathrm{~kg} / \mathrm{cm}^{2} \text { and } 0.7 \\
\mathrm{~kg} / \mathrm{cm}^{2}\end{array}$ & $\begin{array}{l}\text { Carbonation enhanced } \\
\text { sourness, bitterness, } \\
\text { astringency, and } \\
\text { chalkiness, and } \\
\text { repressed sweetness, } \\
\text { cooked aroma, and } \\
\text { flavor }\end{array}$ \\
\hline Yau et al. [21] & $\begin{array}{l}\text { Carbonated } \\
\text { blueberry-flavored } \\
\text { milks }\end{array}$ & $\begin{array}{l}\text { Low fat milk, sweetener, } \\
\text { blueberry concentrate, } \\
\text { natural flavors, } \\
\text { stabilizers }\end{array}$ & 1.4 to $1.5 \mathrm{~kg} / \mathrm{cm}^{2}$ & $\begin{array}{l}\text { Carbonation increased } \\
\text { the flavor intensity of } \\
\text { blueberry and increased } \\
\text { sweetness perception }\end{array}$ \\
\hline \multicolumn{5}{|c|}{ Carbonated Yogurt Beverages } \\
\hline Choi et al. [18] & $\begin{array}{l}\text { Plain and } \\
\text { strawberry } \\
\text { carbonated yogurt } \\
\text { beverages }\end{array}$ & $\begin{array}{l}\text { Whole milk, cream, } \\
\text { NFDM, cane sugar, } \\
\text { stabilizer, L. bulgaricus, S. } \\
\text { thermophilus, strawberry } \\
\text { extract }\end{array}$ & $0.5 \mathrm{~kg} / \mathrm{cm}^{2}$ & $\begin{array}{l}\text { High consumer } \\
\text { acceptance of samples } \\
\text { with } 89.8 \% \text { liking the } \\
\text { product; shelf-life } \\
\text { increased from one to } \\
\text { four months }\end{array}$ \\
\hline $\begin{array}{l}\text { Gueimonde et al. } \\
\text { [17] }\end{array}$ & Fermented milk & $\begin{array}{l}\text { Milk, NFDM, } L \text {. } \\
\text { acidophilus, } S . \\
\text { thermophilus }\end{array}$ & Not measured & $\begin{array}{l}\text { Carbonation decreased } \\
\text { the amount of time taken } \\
\text { to ferment milk into } \\
\text { yogurt }\end{array}$ \\
\hline $\begin{array}{l}\text { Karagul-Yuceer } \\
\text { et al. [22] }\end{array}$ & Yogurt & $\begin{array}{l}\text { Skim milk, cream, } \\
\text { NFDM, sugar, stabilizer, } \\
\text { L. acidophilus, B. longum, } \\
\text { B. lichenformis, E. coli, L. } \\
\text { monocytogenes }\end{array}$ & 0.14 to $0.35 \mathrm{~kg} / \mathrm{cm}^{2}$ & $\begin{array}{l}\text { Carbonation had no } \\
\text { effect on the viability of } \\
\text { yogurt cultures or } \\
\text { pathogenic bacteria }\end{array}$ \\
\hline $\begin{array}{l}\text { Ravindra et al. } \\
\text { [23] }\end{array}$ & $\begin{array}{l}\text { Carbonated } \\
\text { sweetened } \\
\text { fermented dairy } \\
\text { drink }\end{array}$ & $\begin{array}{l}\text { Milk, L. lactis, sugar, } \\
\text { stabilizer }\end{array}$ & $3.5 \mathrm{~kg} / \mathrm{cm}^{2}$ & $\begin{array}{l}\text { Carbonation lengthened } \\
\text { shelf life up to } 12 \text { weeks } \\
\text { by inhibiting lipolysis, } \\
\text { proteolysis, yeast, and } \\
\text { mold }\end{array}$ \\
\hline $\begin{array}{l}\text { Vinderola et al. } \\
\text { [24] }\end{array}$ & Fermented milk & $\begin{array}{l}\text { Milk, NFDM, S. } \\
\text { thermophilus, } L \text {. } \\
\text { acidophilus, B. bifidum }\end{array}$ & Not measured & $\begin{array}{l}\text { Carbonation had no } \\
\text { effect on the viability of } \\
\text { starter cultures; } \\
\text { carbonation successfully } \\
\text { reduced fermentation } \\
\text { time }\end{array}$ \\
\hline Walsh et al. [25] & $\begin{array}{l}\text { Carbonated yogurt } \\
\text { beverage }\end{array}$ & $\begin{array}{l}\text { Whole milk, } L \text {. } \\
\text { acidophilus, L. bulgaricus, } \\
\text { S. thermophilus, } \\
\text { Bifidobacterium, inulin, } \\
\text { sugar, stabilizer, } \\
\text { flavorings, citric acid, } \\
\text { potassium sorbate, } \\
\text { calcium carbonate }\end{array}$ & $0.35 \mathrm{~kg} / \mathrm{cm}^{2} \mathrm{CO}_{2}$ & $\begin{array}{l}\text { L. acidophilus and } \\
\text { Bifidobacterium } \\
\text { maintained levels of } 10^{6} \\
\text { Colony forming unit } \\
\text { (CFU)/g throughout } \\
\text { shelf-life }\end{array}$ \\
\hline \multicolumn{5}{|c|}{ Carbonated Whey, Buttermilk, and Other Beverages } \\
\hline $\begin{array}{l}\text { Abdolmaleki et al. } \\
\text { [11] }\end{array}$ & $\begin{array}{l}\text { Carbonated and } \\
\text { fermented kefir, } \\
\text { whey, and soy } \\
\text { beverages }\end{array}$ & $\begin{array}{l}\text { Whey, milk, soy, L. kefir, } \\
\text { L. brevis, L. casei, L. } \\
\text { plantarum, S. lactis, } \\
\text { Leuconostoc mesenteroides, } \\
\text { Acetobacter aceti, Candida } \\
\text { kefir, Saccharomyces lactis } \\
\text { and S. fragilis }\end{array}$ & Not measured & $\begin{array}{l}\text { Population of yeast } \\
\text { increased over shelf-life } \\
\text { while lactic acid bacteria } \\
\text { decreased in numbers }\end{array}$ \\
\hline
\end{tabular}


Table 2. Cont.

\begin{tabular}{|c|c|c|c|c|}
\hline Author(s) & Base/Substrate & Ingredients & $\begin{array}{l}\text { Carbonation Levels } \\
\text { (given as a pressure) }\end{array}$ & Key Findings \\
\hline $\begin{array}{l}\text { Saint-Eve et al. } \\
\text { [26] }\end{array}$ & Flavored Beverages & $\begin{array}{l}\text { Mineral water, sucrose, } \\
\text { flavorings }\end{array}$ & 0.63 to $0.70 \mathrm{~kg} / \mathrm{cm}^{2}$ & $\begin{array}{l}\text { Carbonation decreased } \\
\text { sweetness perception } \\
\text { and increased sourness } \\
\text { perception, higher levels } \\
\text { of sucrose decreased } \\
\text { perception of freshness }\end{array}$ \\
\hline Shaikh et al. [27] & $\begin{array}{l}\text { Carbonated } \\
\text { buttermilk }\end{array}$ & $\begin{array}{l}\text { Buffalo milk, } S \text {. } \\
\text { thermophilus, } L \text {. } \\
\text { bulgaricus, mango, } \\
\text { pineapple, orange }\end{array}$ & $\begin{array}{l}5.62,7.03, \text { and } \\
8.44 \mathrm{~kg} / \mathrm{cm}^{2}\end{array}$ & $\begin{array}{l}\text { Carbonated beverages } \\
\text { that are acceptable to } \\
\text { consumers can be } \\
\text { created from buttermilk }\end{array}$ \\
\hline Shaikh et al. [28] & $\begin{array}{l}\text { Fermented } \\
\text { carbonated whey } \\
\text { beverage }\end{array}$ & $\begin{array}{l}\text { Whey, } S \text {. thermophilus, } L \text {. } \\
\text { bulgaricus, sugar, orange, } \\
\text { pineapple, kalakhatta }\end{array}$ & $\begin{array}{l}63.42,72.48, \text { and } \\
81.54 \mathrm{~kg} / \mathrm{cm}^{2} \\
\text { *These carbonation } \\
\text { levels seem very } \\
\text { high compared to } \\
\text { other similar studies }\end{array}$ & $\begin{array}{l}\text { Lactic acid and } \\
\text { carbonation helped } \\
\text { mitigate off flavors from } \\
\text { whey, } 72.48 \mathrm{~kg} / \mathrm{cm}^{2} \\
\text { carbonation level } \\
\text { preferred }\end{array}$ \\
\hline Suresha et al. [29] & $\begin{array}{l}\text { Flavored whey } \\
\text { dairy beverage }\end{array}$ & $\begin{array}{l}\text { Whey permeate, citric } \\
\text { acid, flavoring (orange, } \\
\text { pineapple, mango) }\end{array}$ & Not measured & $\begin{array}{l}\text { Carbonation improved } \\
\text { overall acceptability of } \\
\text { beverages and doubled } \\
\text { shelf-life }\end{array}$ \\
\hline \multicolumn{5}{|c|}{ Carbonated Yogurt } \\
\hline Coggins et al. [30] & $\begin{array}{l}\text { Low-fat plain } \\
\text { yogurt; Swiss style } \\
\text { lemon and } \\
\text { strawberry yogurt }\end{array}$ & $\begin{array}{l}\text { Cream, NFDM, sugar, } \\
\text { stabilizer, L. acidophilus, } \\
\text { Bifidobacterium longum }\end{array}$ & 0.08 to $0.09 \mathrm{~kg} / \mathrm{cm}^{2}$ & $\begin{array}{l}\text { Carbonation of yogurt at } \\
\text { this level had no affect } \\
\text { on sensory } \\
\text { characteristics }\end{array}$ \\
\hline Wright et al. [31] & $\begin{array}{l}\text { Carbonated Swiss } \\
\text { style yogurt }\end{array}$ & $\begin{array}{l}\text { Skim milk, NFDM, } \\
\text { stabilizer, sweetener, } \\
\text { thermophilic lactic acid } \\
\text { culture }\end{array}$ & $\begin{array}{l}62 \text { to } 1596 \mathrm{ppm}(0.01 \\
\left.\text { to } 0.07 \mathrm{~kg} / \mathrm{cm}^{2}\right)\end{array}$ & $\begin{array}{l}\text { Ideal amount of } \\
\text { carbonation found } \\
\text { through sensory analysis } \\
\text { is } 263 \mathrm{ppm}\end{array}$ \\
\hline
\end{tabular}

Sensory studies have been performed, showing that carbonated dairy beverages were liked as much as or more than their non-carbonated counterparts. Choi and Kosikowski [18] developed plain and strawberry yogurt beverages that were sweetened with $12 \%$ sucrose and carbonated to $0.5 \mathrm{~kg}$ carbon dioxide per $\mathrm{cm}^{2}$. The carbonated yogurt samples were tested in consumer panels for their likability, with additional testing for shelf life. The strawberry-flavored carbonated yogurt beverages were preferred compared to carbonated unflavored yogurt beverages, and samples with the $12 \%$ sucrose solution addition were preferred compared to those without sucrose. For panelists who liked yogurt and soft drinks, the strawberry carbonated yogurt beverage scored an average of 5.88 out of 7 , with $89.8 \%$ of panelists liking the product.

Other research on consumer acceptance includes either buttermilk or whey, to create carbonated dairy beverages, because they are ingredients that have commonly been byproducts in the dairy industry. In one study, different buttermilks were used in conjunction with sensory panel testing to develop an acceptable carbonated buttermilk product [27]. Likability testing was performed for the levels of sugar, carbonation, and types or fruit added, and these attributes were adjusted to create the optimum drink. A filtered buttermilk with the addition of $12 \%$ sucrose and $24 \%$ pineapple juice was most preferred out of all the samples [27]. Another byproduct of the dairy industry which was incorporated into carbonated dairy beverages was whey permeate, which is a byproduct of whey protein concentrate, and this was studied to ascertain whether it could be successfully used in a carbonated dairy beverage [29]. Mango, orange, and pineapple beverages were developed with the addition of whey permeate, and they were tested with and without carbonation. Even though non-carbonated beverages scored highly on a 9-point hedonic scale for overall likability, with scores over 8.0, carbonation was found to improve the sensory attributes of all products tested. 
Carbonation reportedly improved color, taste, appearance, consistency, and overall acceptability of the non-carbonated versions of these beverages. It should be noted though that this study used five in-house judges for the sensory studies, which may be why the hedonic likability scores were so high, due to an inadequate number of judges. A similar study with whey protein was done by Shaikh et al. [28] to develop a carbonated beverage with whey that came as a byproduct of cheesemaking. Pineapple, orange, and kalakhatta whey beverages were made, and were carbonated at 63,72 , and $81 \mathrm{~kg} \mathrm{CO}_{2}$ per $\mathrm{cm}^{2}$. The data collected from 10 panelists indicated that the pineapple beverage at $72 \mathrm{~kg}$ of $\mathrm{CO}_{2}$ per $\mathrm{cm}^{2}$ was the most highly preferred. These findings were very similar to Suresha and Jayprakash's [20] results.

It is crucial to recognize that the effect that carbonation has on a beverage can vary widely by the amount of carbonation present in the beverage. The level of carbonation will affect the consumers' perception of the final product by altering the sensory attributes of the product. Several studies have tested the carbonation level in Swiss and spoonable style yogurts, and while these studies are not directly related to dairy beverages, the findings are still applicable to these dairy beverages to a certain extent. Coggins et al. [30] prepared carbonated strawberry and lemon swiss style yogurts at $0.08 \mathrm{~kg} / \mathrm{cm}^{2}$ and $0.09 \mathrm{~kg} / \mathrm{cm}^{2}$, and performed consumer tests at 7,21 , and 45 days of shelf life. Trained panelists scored the carbonated yogurts on flavor, texture, and overall acceptability. It was found that there was no significant difference between carbonated and non-carbonated yogurts for all these yogurts. The researchers did point out that the carbonation level was not high enough to have a significant difference, and that carbonation levels would need to be optimized. This was supported by Lederer et al. [20], who used levels of carbonation at $0.07 \mathrm{~kg} / \mathrm{cm}^{2}$ and below, as the low and subthreshold levels of carbonation. It should be noted that the sensory results of Coggins et al. [30] study may be skewed because using trained panelists to determine overall acceptability is not an acceptable practice in sensory science; trained panelists should only be used for analytical sensory testing. Wright et al. [31] performed a study to further research what the ideal amount of carbonation would be in a spoonable Swiss-style yogurt. A total of 13 college-aged panelists were selected and trained to perform the sensory evaluations. Carbonation levels were tested, ranging between 227 and $305 \mathrm{ppm}\left(0.01\right.$ to $\left.0.07 \mathrm{~kg} / \mathrm{cm}^{2}\right)$. It was found that the ideal amount of carbonation was $263 \mathrm{ppm}$ in Swiss-style yogurt. While this was the ideal level of carbonation, the study does not reveal why other carbonation levels were less than ideal, and also mentions that the ideal carbonation level does change depending on hunger, satiety, time of day, etc. Lederer et al. [20] applied different levels of carbonation to raspberry, strawberry-, peach-, and root beer-flavored milks. Three different levels of carbonation were applied, a subthreshold $\left(0.60\right.$ volumes $\mathrm{CO}_{2}$ or $\left.<0.07 \mathrm{~kg} / \mathrm{cm}^{2}\right)$, low $(0.74$ volumes $\mathrm{CO}_{2}$ or $\left.0.07 \mathrm{~kg} / \mathrm{cm}^{2}\right)$, and high $\left(1.42\right.$ volumes $\mathrm{CO}_{2}$ or $\left.0.7 \mathrm{~kg} / \mathrm{cm}^{2}\right)$ level of carbonation. While consumer preference for one level of carbonation was not tested, the effect of different levels of carbonation of specific sensory attributes was evaluated. All levels of carbonation were found to suppress cooked notes in the milk. The higher the levels of carbonation, the more bitterness, sourness, chalky, and astringent notes and the less sweetness perception was perceived for the dairy beverages. Studies like Suresha and Jayprakash [29], Skaikh et al. [28], and Wright et al. [31] support that when carbonation levels are too high, the beverage will exhibit more of the bitter and sour notes, and are unacceptable at these high levels. This supports the idea of having an ideal carbonation level, and gives researchers some idea of what will happen as the carbonation levels are adjusted. Studies like Choi and Kosikowski [18] and Coggins et al. [30] supported the idea that carbonation at subthreshold levels will not improve overall likability of dairy products. The carbonation must be present at detectable levels, $0.07 \mathrm{~kg} / \mathrm{cm}^{2}$ or higher, to have an impact on the consumers perception of the dairy beverage. It is difficult to give an ideal carbonation level for all beverages because each dairy beverage is unique in its attributes such as sweetness levels, protein levels, flavorings, etc.

It is important to research how specific attributes of beverages are altered by carbonation, in order to understand how consumers will react to the changes in these sensory attributes. A study was carried out to examine the relationship between carbonation, sweetness, and other product attributes for a 
blueberry carbonated milk drink [21]. Trained panelists were used to determine the flavor intensity, sweetness, blueberry flavor, and viscosity. It was concluded that carbonation significantly enhanced the sweetness, blueberry, and flavor intensity of the milk beverages, and that the viscosity of the beverage was not affected by carbonation. Lederer et al. [20] found contradictory results when compared with Yau's et al. study [21]. While Yau et al. [21] did not vary the levels of carbonation, they reported that carbonation enhanced sweetness, while Lederer et al. found that higher levels of carbonation would reduce sweetness. In addition to sweetness perception, it was found that carbonation will increase bitterness, sourness, chalky, and astringent notes [20]. While there is some contradictory information between the sensory studies on sweetness perception, a more recent study done by Saint-Eve et al. [26] provides some needed clarification, especially on sweetness perception. Sensory results were collected from 10 trained panelists who performed an analysis on beverages where the level of carbonation, sucrose, and flavorings were varied [26]. The results showed a decrease in sweetness perception as the level of carbonation increased. These results disagree with results from Yau et al. [21] but are supported by Lederer et al. [20]. These studies and results are inconsistent, because the various beverages studied contained different amounts of sucrose or sweetener and carbonation. The higher the amount of sucrose, the less carbonation could be detected [26]. Saint-Eve's et al. results were consistent with, and determined that results showing that an increase in carbonation will lead to an increase in sourness and an increase in aroma perception are accurate.

\subsection{Shelf Life}

Sensory studies performed on dairy beverages with carbonation have indicated that carbonation has an effect on several different key attributes of beverages such as sweetness, aroma, texture, and flavor attributes. The primary reason that carbonation is used in beverages is to provide a refreshing or thirst-quenching effect. While some research has shown promise, with up to $89.8 \%$ of panelists liking carbonated dairy beverages [18], carbonation can do more than just make products which are refreshing and taste good. Dairy products typically have a short shelf life of around 30-45 days, depending on the product. The addition of carbonation to dairy beverages has been shown to effectively increase the shelf life of some dairy beverages from one month to up to four months, as shown with some carbonated strawberry yogurt beverages [18].

The shelf-life of dairy products (one to three weeks) is limited by enzyme activity, which leads to off-flavors or microbiological spoilage, usually caused by gram-negative psychotrophic bacteria, yeasts, and molds [32]. As mentioned above, the addition of carbon dioxide to the dairy products, either before processing or when added to the finished product, effectively extends the shelf life. The three ways in which shelf life is lengthened by carbonation are by removing oxygen from the headspace, which inhibits some microbial growth, lowering of the $\mathrm{pH}$ of the product due to the formation of carbonic acid, and the effect that carbon dioxide has on the metabolism of spoilage microorganisms [32]. The addition of carbon dioxide has been shown to increase the shelf life of a broad array of dairy products by as much as 200 to $400 \%$. Chang and Zhang [19] had similar shelf-life extension results, reporting that carbon dioxide reduced the growth of spoilage microorganisms at refrigerated temperatures, however, the same was found to not be true for milk held at room temperature.

Ravindra et al. [23] confirmed the findings of Hotchkiss et al. [32] that dissolved carbon dioxide extends the shelf life significantly in dairy beverages. Carbonated samples of yogurt were put through a sensory panel and compared to a control on a weekly basis. Non-carbonated controls developed off-flavors and were rejected by the fifth week of storage, whereas carbonated samples lasted through 12 weeks of refrigerated storage. Ravindra et al. [23] and Choi and Kosikowski [18] both confirmed that carbonation reduced the amount of yeast and mold growth throughout shelf life. Lipolysis and proteolysis leads to byproducts in dairy products which produces common off-flavors. The off-flavor byproducts are free fatty acids and smaller peptide chains, although the studies do not mention which ones are present at the end of shelf-life. Carbonation reduced the rate and proliferation of these reactions to significantly reduce the amount of byproducts and extend the shelf life of the dairy 
beverages. Carbonated products such as kefir have been studied for physical and chemical changes over shelf-life which relate to the overall quality of the beverage [11]. The drawback to some studies is that the samples of kefir which were made from milk, whey, and soya were only held for analysis for four weeks, a short time, and the samples were never found to be unacceptable by the end of the analysis period. The key findings were that the amount of yeast increased over shelf-life, while lactobacilli and lactococci decreased over shelf-life, along with a decrease in $\mathrm{pH}$ from 4.40 to 4.34 .

Chang and Zhang [19] reported an increase in viscosity over shelf-life for carbonated samples; however, upon looking at the results, the viscosities were almost the same as they showed no significant difference from the controls. In addition to being able to extend shelf-life, the addition of carbon dioxide to dairy beverages is able to reduce the fermentation time for yogurts and save production plants both time and money with the increased efficiency. Gueimonde and Clara [17] used three different strains of $S$. thermophilus and three different strains of L. acidophilus to prove the reduction in fermentation time. Carbon dioxide was added to the milk before fermentation, where the carbonation lowered the $\mathrm{pH}$ of the milk. The lower $\mathrm{pH}$ decreased the lag phase of the L. acidophilus and favored the growth of some of the $S$. thermophilus strains, which led to reduced fermentation times of under $6 \mathrm{~h}$.

\subsection{Probiotic Survival}

Walsh et al. [25] performed a study on vanilla and pomegranate carbonated and non-carbonated drinkable yogurts that were served to 23 panelists. The statistical data from the consumer panels showed that there was no significant difference between the likability scores of the pomegranate carbonated and non-carbonated samples, however, there was a significant difference between the vanilla carbonated and non-carbonated samples. However, the carbonation was not seen as a negative attribute, and likability was mainly due to preference. It should be noted that when studying consumer acceptance, there should be more than 23 panelists (ideally 100+) in order to draw valid conclusions from the data. Walsh et al. [25], while performing shelf-life studies for nine weeks, also performed some probiotic survival studies. Probiotics, "are a desirable natural tool to maintain the healthy balance of the human intestinal microflora, playing an important role in resistance to pathogen colonization in the intestinal, respiratory, and urogenital tract [25]". Given the associated health benefits, there has been a considerable interest from the public in probiotics. Since carbonation can have a bactericidal effect as illustrated by Abdolmaleki et al. [11], it is important to know how carbonation effects the probiotic levels in yogurt.

Two valuable probiotics L. acidophilus and Bifidobacterium were studied over the course of nine weeks while being subjected to carbonated conditions of two volumes of $\mathrm{CO}_{2}$ by Walsh et al. [25]. These probiotics maintained their levels over shelf-life of more than $10^{6}$ colony forming units (CFU) per $\mathrm{g}$ of product, showing no significant differences between them and their non-carbonated counterparts.

There have been studies done prior to the study done by Walsh et al. [25] to support the conclusions that probiotics levels are not significantly affected by the addition of carbonation. Other research has been done to enumerate two different probiotic blends and their performance in fermented milk products over the course of 50 days, which is similar to Walsh's et al. study. Like in the previous study, a blend of L. acidophilus and S. thermophilus was used, as well as a blend of S. thermophilus, L. acidophilus, and Bifidobacterium bifidum [24]. The recommended level for probiotics to remain above and still be effective to the host is $10^{5}$ to $10^{6} \mathrm{CFU} / \mathrm{g}$ through the end of shelf-life [24]. Samples with both blends were compared in their carbonated and non-carbonated versions, and it was effectively shown that the $S$. thermophilus/L. acidophilus blend remained above $10^{6} \mathrm{CFU} / \mathrm{g}$ through the end of shelf life. However, in the S. thermophilus/L. acidophilus/Bifidobacterium bifidum blend, the Bifidobacterium remained at the appropriate levels, but the L. acidophilus dropped off in counts in the carbonated sample compared to the non-carbonated sample. Karagul-Yuceer et al. [22] studied culture and probiotic content of carbonated yogurts up to 90 days, a much longer time than the previous two studies. Slightly different bacterial cultures were used, S. thermophilus, L. bulgaricus, L. acidophilus, and Bifidobacterium longum. The effect of carbonation upon the pathogens Bacillus licheniformis, Escherichia 
coli, and Listeria monocytogenes was also evaluated. While there was no bactericidal effect upon the pathogenic bacteria, normal culture bacteria levels were found not to be affected by carbonation. The mean population of S. thermophilus, L. bulgaricus, and L. acidophilus, remained at about $10^{6} \mathrm{CFU} / \mathrm{g}$, while Bifidobacterium longum was at around $10^{3} \mathrm{CFU} / \mathrm{g}$. The important finding was that these levels were not significantly different between non-carbonated and carbonated samples.

\section{Discussion: Challenges and Opportunities}

\subsection{Challenges}

Gaining consumer acceptance of carbonated drinkable dairy beverages remains a challenge that needs to be overcome in order to increase the popularity of these beverages, especially in the United States. There are several different factors that may affect the popularity of these beverages. The distribution and production of these beverages is currently limited, which means that most of the population is not familiar with or willing to try carbonated dairy beverages. To market carbonated dairy drinks and to increase the consumers' willingness to buy these beverages, it is important to have the necessary data collected from well-performed consumer studies. Consumer studies are typically done to test consumers' reactions to potential food products and their attributes. Many of the consumer studies that are currently available either used an insufficient number of panelists [28,29], or used panelists improperly by using trained panelists to perform likability tests [29]. Other current studies done on carbonated dairy beverages are limited in scope in either the product attributes that were tested, or in the types of beverages that were tested. Many of the beverages studied are created in a lab setting around a very specific ingredient like whey [28], and thus the study is limited in scope. Creating more research-driven data on sensory properties and consumer acceptance of carbonated dairy beverages is both a challenge and an opportunity to be taken. To increase the understanding of consumers' reactions to carbonated yogurt products and to understand how to develop these carbonated products properly, more sensory and consumer studies will need to be performed on a much larger scale and scope.

It is important that carbonated dairy beverage quality is aligned with the consumers' expectations found during consumer testing. Walsh et al. [25] found that carbonated dairy milk or yogurt can separate over the shelf-life term if it is not stabilized with the proper pectin. Separation in dairy products is not typically acceptable to consumers. Other quality defects in carbonated beverages include too much or too little carbonation, off-flavors, undesirable viscosity, and improper flavor delivery. All these issues are not extremely difficult to resolve; however, if the proper studies, especially consumer studies are not performed, these issues can prove to be detrimental to carbonated dairy products.

One of the greatest challenges to consider when discussing how to drive the consumption of carbonated dairy beverages is the decreasing consumption of milk/dairy. Historically, children have been the largest consumers of milk products, while milk and dairy drinks have appealed much less to adults. In recent decades milk has been consumed less and less by children and is being replaced with the consumption of sugary, naturally/artificially flavored, non-nutritive sweetened, carbonated beverages [33]. The age group that consumes the most of these sugary carbonated soft drinks are adolescents. While the consumption of dairy is declining, the children and adolescents who consume these highly sweetened sugary beverages on average consume $14.9 \%$ more calories in their day, which is thought to be a key contributor to childhood obesity [33]. This trend of declining dairy consumption has been confirmed by Hambleton [34]. According to Hambleton [34] while dairy consumption is reducing across all categories, the lowest rates of consumption are among the younger generations, especially the iGeneration and millennials. The decrease in dairy consumption and its current public perception make it exceptionally difficult to market any sort of carbonated dairy beverage to the US population. More widely available nutritious options like a carbonated dairy beverage would be a good replacement for the sugary beverages that children and adolescents consume. 


\subsection{Opportunities}

One differentiation between dairy milk and yogurt is that yogurt is seen as being healthy, mainly due to the probiotics which are in many yogurts. With the decline in the amount of carbonated soft drinks being sold and consumed, there is an opportunity for other carbonated beverages to be sold to replace soft drinks. At the right level, carbonation has a positive impact on the sensory, flavor, and overall effects of beverages in general, not just soft drinks. Non-dairy carbonated beverages are another opportunity that should be leveraged and explored when marketing replacements for sugary soft drinks and other non-nutrient dense beverage options.

While dairy, especially milk, has been declining in consumption and sales in recent years, one bright spot for the dairy industry has been yogurt consumption and sales. The popularity of yogurt would make a carbonated drinkable yogurt an ideal product to boost carbonated dairy sales. According to Douaud [35] as of 2007 yogurt drinks have exhibited a 45 to $49 \%$ growth in 29 different countries. However, the United States only exhibited a 5\% growth, though since 2012 the growth has increased to $66 \%$ by 2017 [1]. With the increasing popularity of drinkable yogurts, Allgeyer et al. [3] notes that consumers perceive yogurt to be healthy mainly because of the probiotic content of yogurt. Most consumers do not understand what probiotics are or what they do for the human body, but they understand that probiotics are healthy and therefore yogurt carries a health halo. Unfortunately, there has not been extensive research done on what kind of yogurt drinks consumers prefer the most. In some studies, it has been found that yogurt drinks with medium sweetness and higher viscosity are preferred to thinner drinkable yogurts, which gives some guidance as to what kind of carbonated yogurt drinks would do better on the market [3].

Carbonation is a positive attribute to add to yogurt drinks because carbonation has a thirst quenching and refreshing effect on consumers, which helps drive beverage consumption. Peyrot des Gachones et al. [36] conducted a study with 10 participants to examine the effects of carbonation upon the thirst of individuals. The participants fasted, and after fasting drank water samples, both carbonated and non-carbonated at different temperatures, and then they were asked to estimate how much water they consumed. Participants estimated that they were drinking $22 \%$ more of the water when the carbonated water was consumed, compared to when the water was not carbonated. Thus the thirst quenching effects of the water were enhanced by carbonation, and also by the coldness or temperature of the water. It was theorized that the increased activity of the pain receptors in the mouth, called nociceptors, increase the perception of more liquid being ingested. Hewson et al. [37] supports this conclusion by saying, "The oral sensation experienced due to carbonation has been described as tingling, prickling, and even pain. Consumers, however, enjoy this 'irritating' stimuli and there is a large market for carbonated beverages in western society." While the Hewson et al. [37] study does not apply to carbonated dairy beverages specifically because only water was studied, it does bring to light some opportunities for further study. More research needs to be done to demonstrate this thirst quenching effect of carbonation in a dairy based-setting seeing that it is a more complex system than water. Hewson et al. [37] also stated that some sensory results, such as what was found by Lederer et al. [23], may vary because the final sensory experience is also altered by the sweetness level, carbonation level, and other flavors in the milk. The carbonation level must be balanced with the sweetness level, which mitigates the carbonation sensory effects, in order to create a desirable product without too many sour and bitter notes present from the carbonation.

Given the general liking of western societies for carbonated beverages, coupled with the decreased sales and popularity of carbonated soft drinks, there is an undeniable white space in the market for a more nutritious carbonated beverage, such as a carbonated dairy beverage. According to Goel-lal [38] the top three non-alcoholic beverage segments in the United States are carbonated drinks, dairy/dairy-alternative drinks, and juice/juice drinks. Carbonated soft drinks and juice/juice drinks have recently seen declines in sales mainly because they are challenged by the image of being sugary beverages. Many of the consumers of carbonated soft drinks are increasingly consuming other types of sparkling beverages more often than carbonated soft drinks, such as carbonated waters [39]. There 
is much competition between carbonated soft drink sales and other sparkling beverage sales, as other sparkling beverages are now becoming increasingly popular. This gives carbonated dairy beverages an increasing opportunity to edge into the market with other sparkling drinks and to be used on other usage occasions. Shah [40] created a carbonated yogurt beverage with a new probiotic strain, L. helveticus, because of the need for a replacement for carbonated soft drinks in western societies. The health benefits of probiotics in a dairy setting, combined with the positive sensory attributes of carbonation, creates a good opportunity for carbonated dairy beverages.

Lastly, the dairy free trend should not be overlooked when considering the addition of new carbonated beverages to the market. The non-dairy trend is currently being led by almond milk, with many consumers looking to dairy-free consumables for variety or other health benefits [41]. Many of the non-dairy products are meant to mimic dairy products on the market, and creating a carbonated dairy or non-dairy type milk product would be smart, given the current market trends.

\section{Conclusions}

The most popularly consumed carbonated dairy beverage in the United States is kefir, which is carbonated by the addition of kefir grains that contain yeast. Other yeast-carbonated and dairy beverages which are carbonated have not been popular or mainstream in the United States. Sensory studies performed on carbonated dairy products and beverages have been varied, studying aspects such as the effect of carbonation on sweetness, sourness, bitterness, and other product attributes. There is still much need for more studies to be performed on how carbonation affects the sensory attributes of carbonated dairy drinks. Other studies on carbonated dairy beverages have shown that carbonation can significantly increase shelf-life, and that carbonation does not affect probiotic levels in yogurt. Carbonated dairy beverages face challenges in becoming popular because there is a lack of proper research on these beverages, and there is a current decline in dairy popularity and consumption in the United States. However, there are many opportunities to study and popularize carbonated dairy yogurt drinks, and even carbonated non-dairy yogurt drinks. Overall, carbonated dairy beverages are a small category that deserves more attention and academic research to study its attributes, pros, and cons.

Author Contributions: Conceptualization, D.N. and K.K.; Methodology, D.N.; Writing-Review \& Editing, K.K.

Funding: This research received no external funding.

Conflicts of Interest: The authors declare no conflict of interest.

\section{References}

1. Hambleton, M. Yogurt and Yogurt Drinks-US; Mintel: New York, NY, USA, 2017.

2. Sisel, E. Yogurt and Yogurt Drinks-US; Mintel: New York, NY, USA, 2015.

3. Allgeyer, L.; Miller, M.; Lee, S. Drivers of Liking for Yogurt Drinks with Prebiotics and Probiotics. J. Food Sci. 2010, 75, S212-S219. [CrossRef] [PubMed]

4. Tamime, A.Y.; Robinson, R.K. Tamime and Robinson's Yoghurt Science and Technology, 3rd ed.; Woodhead Publishing: Cambridge, UK, 2007; p. 791.

5. Tamime, A.Y.; Muir, D.D.; Wszolek, M. Kefir, Koumiss and Kishk. Dairy Ind. Int. 1999, 64, 32-33.

6. Arslan, S. A review: Chemical, microbiological and nutritional characteristics of kefir. CYTA-J. Food 2015, 13, 340-345. [CrossRef]

7. Olsen, P.R. Private Sector; Adding Fizz to the Dairy Case. New York Times, 2 November 2003.

8. Aryana, K.J.; Olson, D.W. A 100-Year Review: Yogurt and other cultured dairy products. J. Dairy Sci. 2017, 100, 9987-10013. [CrossRef] [PubMed]

9. Ahmed, Z.; Wang, Y.; Ahmad, A.; Khan, S.T.; Nisa, M.; Ahmad, H.; Afreen, A. Kefir and Health: A Contemporary Perspective. Crit. Rev. Food Sci. Nutr. 2013, 53, 422-434. [CrossRef] [PubMed]

10. Guzel-Seydim, Z.B.; Kok-tas, T.; Greene, A.K.; Seydim, A.C. Review: Functional Properties of Kefir. Crit. Rev. Food Sci. Nutr. 2011, 51, 261-268. [CrossRef] [PubMed] 
11. Abdolmaleki, F.; Assadi, M.M.; Akbarirad, H. Assessment of beverages made from milk, soya milk and whey using Iranian kefir starter culture. Int. J. Dairy Technol. 2015, 68, 441-447. [CrossRef]

12. Bai, L.; Ji, S. Isolation and Identification of Lactic Acid Bacteria from Koumiss in Eastern Inner Mongolia of China. Am. Inst. Phys. Conf. Ser. 2017, 1794, 505.

13. Mu, Z.S.; Yang, X.J.; Yuan, H.L. Detection and Identification of Wild Yeast in Koumiss. Food Microbiol. 2012, 31, 301-308. [CrossRef] [PubMed]

14. Sviatokha, N.; Filimonova, I. Koumiss Therapy as Upcoming Trend for Development of Tourism in Russia; IEEE: Piscataway, NJ, USA, 2017; Volume 464.

15. Igoe, R.S.; Taylor, R.J. Yogurt Milk Shake. U.S. Patent EP0059617, 8 September 1982.

16. Castberg, H.B.; Rysstad, G.; Tracey, M.A. Carbonated Milk. U.S. Patent WO1989002221A1, 23 March 1989.

17. Gueimonde, M.; Clara, G. Reduction of incubation time in carbonated Streptococcus thermophilus/Lactobacillus acidophilus fermented milks as affected by the growth and acidification capacity of the starter strains. Milchwissenschaft 2004, 59, 280-283.

18. Choi, H.S.; Kosikowski, H.V. Sweetened Plain and Flavored Carbonated Yogurt Beverages. J. Dairy Sci. 1985, 68, 613-619. [CrossRef]

19. Chang, M.K.; Zhang, H. Carbonated Milk: Proteins. J. Food Sci. 1992, 57, 880-882. [CrossRef]

20. Lederer, C.L.; Bodyfelt, F.W.; McDaniel, M.R. The Effect of Carbonation Level on the Sensory Properties of Flavored Milk Beverages. J. Dairy Sci. 1991, 74, 2100-2108. [CrossRef]

21. Yau, N.J.N.; McDaniel, M.R.; Bodyfelt, F.W. Sensory Evaluation of Sweetened Flavored Carbonated Milk Beverages. J. Dairy Sci. 1989, 72, 367-377. [CrossRef]

22. Karagul-Yuceer, Y.; Wilson, J.C.; White, C.H. Formulations and Processing of Yogurt Affect the Microbial Quality of Carbonated Yogurt. J. Dairy Sci. 2001, 84, 543-550. [CrossRef]

23. Ravindra, M.R.; Rao, K.J.; Nath, B.S.; Ram, C. Carbonated fermented dairy drink-effect on quality and shelf life. J. Food Sci. Technol. 2014, 51, 3397-3403. [CrossRef] [PubMed]

24. Vinderola, C.G.; Gueimonde, M.; Delgado, T.; Reinheimer, J.A.; Reyes-Gavilan, C.G. Characteristics of Carbonated Fermented Milk and Survival of Probiotic Bacteria. Int. J. Dairy Technol. 2000, 10, $213-220$. [CrossRef]

25. Walsh, H.; Cheng, J.J.; Guo, M.R. Effects of Carbonation on Probiotic Survivability, Physicochemical, and Sensory Properties of Milk-Based Symbiotic Beverages. J. Food Sci. 2014, 79, M604-M613. [CrossRef] [PubMed]

26. Saint-Eve, A.; Deleris, I.; Feron, G.; Ibarra, D.; Guichard, E.; Souchon, I. How trigeminal, taste and aroma perceptions are affected in mint-flavored carbonatedbeverages. Food Qual. Prefer. 2010, 21, 1026-1033. [CrossRef]

27. Shaikh, M.F.B.; Rathi, S.D. Utilisation of buttermilk for the preparation of carbonated fruit-flavoured beverages. J. Dairy Sci. 2009, 62, 564-570. [CrossRef]

28. Shaikh, S.Y.; Rathi, S.D.; Pawar, V.D.; Agarkar, B.S. Studies on Development of a Process for Preparation of Fermented Carbonated Whey Beverage. J. Food Sci. 2001, 38, 519-521.

29. Suresha, K.B.; Jayprakash, H.M. Utilisation of ultra filtration whey permeate for preparation of beverage. J. Dairy Sci. 2003, 56, 278-284.

30. Coggins, P.C.; Karagul-Yuceer, Y.; Wilson, J.C.; White, C.H. Carbonated Yogurt-Sensory Pro perties and Consumer Acceptance. J. Dairy Sci. 1999, 82, 1394-1398.

31. Wright, A.O.; Ogden, L.V.; Eggett, D.L. Determination of carbonation threshold in yogurt. J. Food Sci. 2003, 68, 378-381. [CrossRef]

32. Hotchkiss, J.H.; Werner, B.G.; Lee, E.Y.C. Addition of Carbon Dioxide to Dairy Products to Improve Quality: A Comprehensive Review. Compr. Rev. Food Sci. Food Saf. 2006, 5, 158-168. [CrossRef]

33. Ozen, A.E.; Bibiloni, M.D.; Pons, A.; Tur, J.A. Fluid intake from beverages across age groups: A systematic review. J. Hum. Nutr. Diet. 2015, 28, 417-442. [CrossRef] [PubMed]

34. Hambleton, M. Dairy Milk-US; Mintel: New York, NY, USA, 2017.

35. Douaud, C. Yogurt Drinks Are Leading Food and Beverage Product; Food Navigator: Chicago, IL, USA, 2007.

36. Peyrot Des Gachons, C.; Avrillier, J.; Gleason, M.; Algarra, L.; Zhang, S.; Mura, E.; Nagai, H.; Breslin, P.A.S. Oral cooling and carbonation increase the perception of drinking and thirst quenching in thirsty adults. PLoS ONE 2016, 11, e0162261. [CrossRef] [PubMed] 
37. Hewson, L.; Hollowood, T.; Chandra, S.; Hort, J. Gustatory, Olfactory and Trigeminal Interactions in a Model Carbonated Beverage. Chemosens. Percept. 2009, 2, 94-107. [CrossRef]

38. Goel-lal, G. Non-Alcoholic Beverages: The Market-US; Mintel: New York, NY, USA, 2011.

39. Bonnett, M. Carbonated Soft Drinks-US; Mintel: New York, NY, USA, 2018.

40. Shah, N.; Prajapati, J.B. Effect of carbon dioxide on sensory attributes, physico-chemical parameters and viability of Probiotic L-helveticus MTCC 5463 in fermented milk. J. Food Sci. Technol. 2014, 51, 3886-3893. [CrossRef] [PubMed]

41. Hambleton, M. Non-Dairy Milk-US; Mintel: New York, NY, USA, 2017.

(C) 2018 by the authors. Licensee MDPI, Basel, Switzerland. This article is an open access article distributed under the terms and conditions of the Creative Commons Attribution (CC BY) license (http://creativecommons.org/licenses/by/4.0/). 